\title{
ANALISIS PERUBAHAN KUANTITAS MATERIAL KOLOM BETON BERTULANG PADA MODEL STRUKTUR BANGUNAN GEDUNG SEDERHANA
}

\author{
Mubarak $^{* 1}$, Abdullah ${ }^{1}$, Medyan Riza ${ }^{2}$ dan Yulia Hayati ${ }^{1}$ \\ 1Dosen / Jurusan Teknik Sipil / Universitas Syiah Kuala \\ 2 Dosen / Program Studi Doktor Ilmu Teknik / Universitas Syiah Kuala \\ Korespondensi: mubarak@unsyiah.ac.id
}

\begin{abstract}
The loading aspect of a building is one of the factors that varies the dimensions of building components. Differences in building site areas are also contributed to the load received by buildings, especially in terms of earthquake loads. For the Province of Aceh with relatively high levels of earthquake vulnerability, the problems of structure dimensions change that caused by earthquake need to be specified. Changes to dimensions will affect the quantity of works, and furthermore against the building price standard. This research conducted to analyze the change of material quantity caused by earthquake load changes based on indication of acceleration of spectral response. This study was conducted by developing a model of simple building structure design and load change analyzed in 8 earthquake zones as specified in standard SNI 1726:2012. The analysis focused specifically on the structural components of reinforced concrete columns. The information obtained from the analysis explains the effect of earthquake load changes from each of the observed zones on the use of reinforcing steel materials. The same condition is also seen in the ratio of reinforcement usage per cubic meter of concrete. The changes begin to be seen when the building model is positioned on zone 14 with an acceleration of $1.19 \mathrm{~g}$ spectrum response.
\end{abstract}

Keywords: reinforced concrete, column, dimension, material quantity, earthquake

\section{PENDAHULUAN}

Potensi bencana yang disebabkan oleh gempa bumi merupakan kondisi yang perlu menjadi perhatian serius. Frekuensi dan intensitas gempa di Indonesia dapat dikategorikan relatif tinggi dibandingkan sejumlah negara lain di Asia Tenggara. Peristiwa gempa yang terjadi dalam beberapa tahun terakhir telah menimbulkan berbagai kerusakan pada infrastruktur publik bahkan juga telah merenggut korban jiwa penduduk pada wilayah terdampak. Upaya meminimalisir dampak korban jiwa perlu dilakukan melalui upaya penyediaan infrastruktur yang tahan gempa [1]. Konsep mitigasi yang dikembangkan adalah, bila gempa terjadi, elemen struktural dan non-struktural boleh rusak, namun struktur bangunan tidak roboh sehingga korban jiwa dapat diminimalisir. Kerawanan suatu wilayah terhadap gempa bumi dapat diketahui dengan mengacu pada Peta Zonasi Gempa Indonesia
Tahun 2010 (SNI 1726:2012) dan saat ini terus diperbaharui sesuai informasi kegempaan terbaru [2].

Bangunan gedung merupakan salah satu infrastruktur yang perlu direncanakan tahan terhadap gempa [3]. Komponen struktur sebuah bangunan menjadi prioritas untuk direncanakan dengan tidak memperhatikan aspek teknis semata, namun juga tetap memperhitungkan aspek efisiensi dan ekonomis [4]. Pertimbangan ini diperlukan mengingat komponen struktur merupakan komponen yang memberi kontribusi terbesar terhadap total biaya sebuah bangunan gedung [5][6]. Pada bangunan gedung yang menggunakan struktur beton bertulang, kontribusi terhadap biaya ditentukan oleh dominannya jumlah dan harga material yang digunakan, seperti semen, agregat, dan baja tulangan [7].

Dimensi yang direncanakan pada struktur sebuah bangunan merupakan variabel masukan 
dalam proses analisis biaya konstruksi. Dimensi merupakan informasi yang dibutuhkan untuk menganalisis kuantitas sebuah pekerjaan. Terkait dengan konstruksi beton bertulang, kuantitas dan harga ditentukan oleh komponen pekerjaan beton, pekerjaan pembesian, dan pekerjaan bekisting [8][9][10]. Penentuan dimensi dipengaruhi oleh beban rencana yang bekerja pada suatu komponen struktur bangunan. Beban struktur sebuah bangunan dapat bersumber dari berat seluruh bahan bangunan, penghuni, barang-barang yang ada di dalam bangunan gedung, efek lingkungan, selisih perpindahan, dan gaya kekangan akibat perubahan dimensi.

Proses penentuan dimensi ditentukan oleh wilayah terkait dengan zonasi gempa. Diperlukan upaya untuk menganalisis dampak perbedaan zonasi tersebut terhadap perubahan dimensi struktur bangunan, dan lebih jauh pada perubahan kuantitas material. Identifikasi pola perubahan yang timbul pada dimensi dan kuantitas merupakan langkah awal dari kajian yang lebih luas terkait standar biaya bangunan di tiap wilayah. Mencermati permasalahan tersebut, penelitian ini ditujukan untuk menganalisis perubahan kuantitas material yang terjadi akibat perubahan beban gempa pada tiap wilayah di Provinsi Aceh. Analisis difokuskan pada komponen struktur kolom beton bertulang dari sebuah model struktur bangunan gedung sederhana.

\section{METODE PENELITIAN}

\subsection{Pemodelan Struktur Bangunan Gedung}

Struktur bangunan gedung merupakan objek yang dianalisis pada penelitian ini. Bentuk dan dimensi struktur bangunan tersebut dimodelkan sesuai dengan klasifikasi sederhana mengacu pada kriteria dalam Permen PU No. 45/PRT/M/2007 tentang pedoman teknis pembangunan bangunan gedung negara [11] Bangunan sederhana merupakan bangunan dengan tinggi maksimum 2 lantai dan luas bangunan kurang dari $500 \mathrm{~m}^{2}$. Model struktur bangunan yang direncanakan dalam penelitian ini memiliki ukuran luas tiap level lantai gedung (Li $220 \mathrm{~m}^{2}$ dan total luas lantai $(L) 440 \mathrm{~m}^{2}$. Ketinggian setiap level lantai $\left(T_{i}\right) 4 \mathrm{~m}$ dan total tinggi bangunan (T) $8 \mathrm{~m}$. Desain model struktur tersebut ditunjukkan pada Gambar 1.

Model struktur bangunan dianalisis dengan menempatkan desain tersebut pada sejumlah wilayah di Provinsi Aceh sesuai dengan pembagian zonasi gempa wilayah tersebut. Sesuai dengan Peta Zonasi Gempa Indonesia, wilayah Provinsi Aceh terbagi dalam sejumlah zona, mulai dari Zona 10 sampai dengan Zona 19 (Gambar 2). Setiap zona dibedakan oleh nilai percepatan respon spektra $(R S)$, yaitu satuan yang diukur dalam $g$ (akselerasi karena gravitasi bumi, g-force) yang menggambarkan percepatan maksimum dalam gempa bumi pada objek.

\subsection{Analisis Dimensi}

Dimensi struktur bangunan gedung secara umum dan khususnya pada struktur kolom beton bertulang dianalisis berdasarkan acuan SNI sebagai berikut :

a. SNI 1726:2012 tentang tata cara perencanaan ketahanan gempa untuk struktur bangunan gedung dan non-gedung [2];

b. SNI 1727:2013 tentang beban minimum untuk perencanaan bangunan gedung dan struktur lain [12]; dan

c. SNI 2847:2013 tentang persyaratan beton struktural untuk bangunan gedung [13].

Proses analisis dimensi dilakukan sesuai dengan tahapan berikut :

1) Analisis beban gempa

a) Gempa rencana, kategori risiko struktur bangunan, dan faktor keutamaan

Mengacu pada SNI 1726:2012 Pasal 4.1, gempa rencana ditetapkan sebagai gempa yang kemungkinan terlewati besarannya selama 50 tahun umur struktur bangunan sebesar 2 persen. Kategori risiko struktur bangunan ditetapkan dalam kategori I dan II dengan faktor keutamaan gempa 1,0 .

b) Kombinasi beban dan pengaruh beban gempa

Kombinasi beban direncanakan mengacu pada SNI 1726:2012 Pasal 4.2.

c) Klasifikasi situs

Klasifikasi situs diasumsikan berada pada Kelas Situs SD (tanah sedang), sebagaimana dijelaskan pada SNI 1726:2012 Pasal 5.

d) Wilayah gempa dan spektrum respon Wilayah gempa yang ditinjau ditetapkan sesuai zonasi gempa untuk Wilayah Aceh (Gambar 2), dan dianalisis mengacu pada SNI 1726:2012 
Pasal 6.

2) Analisis struktur kolom beton bertulang

a) Perencanaan struktur bangunan gedung Perencanaan struktur bangunan gedung secara umum dilakukan dengan berpedoman pada ketentuan tersebut dalam SNI 1726:2012 Pasal 7.

b) Kekuatan Desain

Material beton dan tulangan baja direncanakan menggunakan mutu beton $\left(f^{\prime} c\right) 25 \mathrm{MPa}$ dan mutu baja ulir $(f y) 400$ $\mathrm{MPa}$.

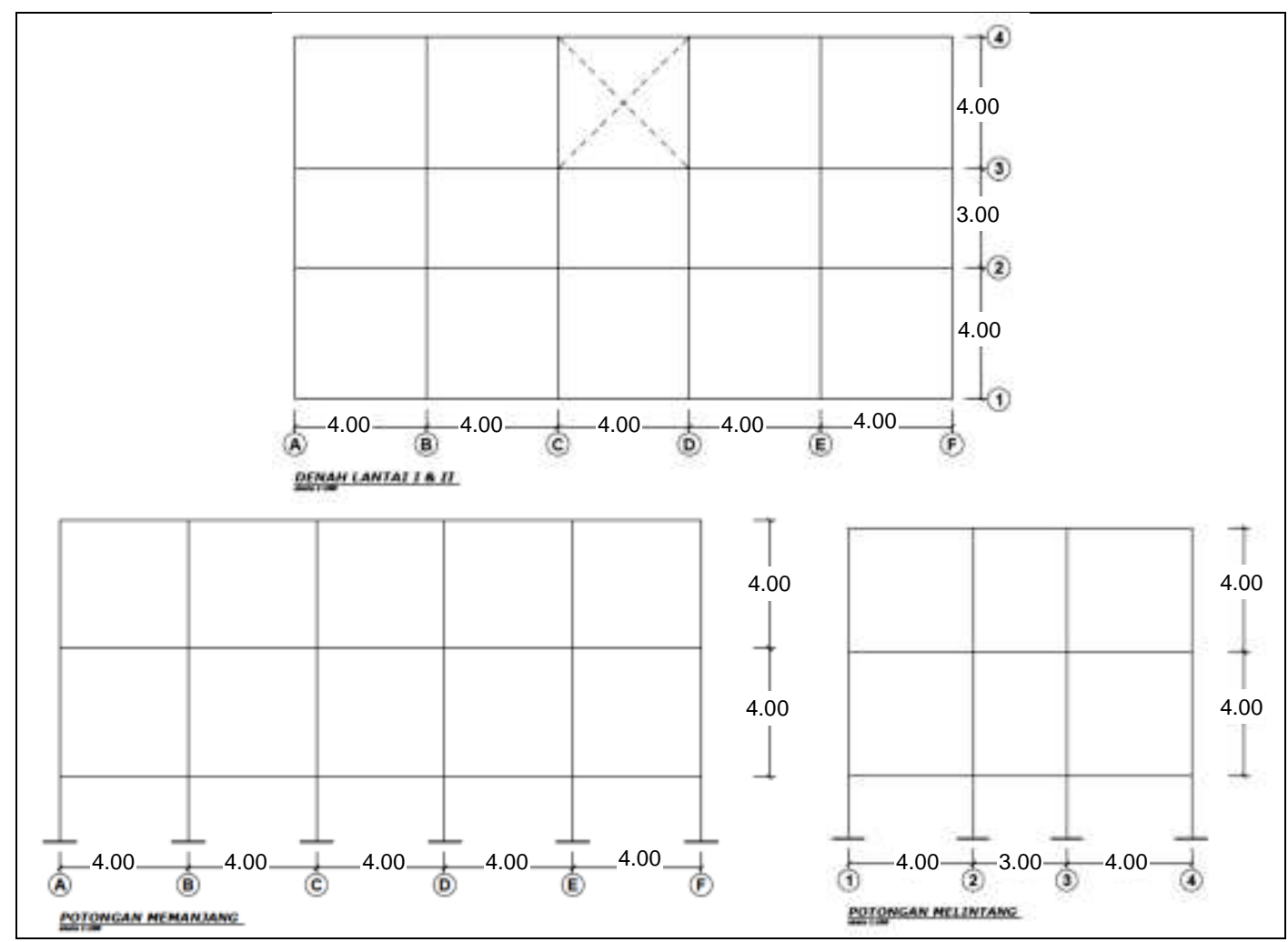

Gambar 1. Model desain struktur bangunan sederhana

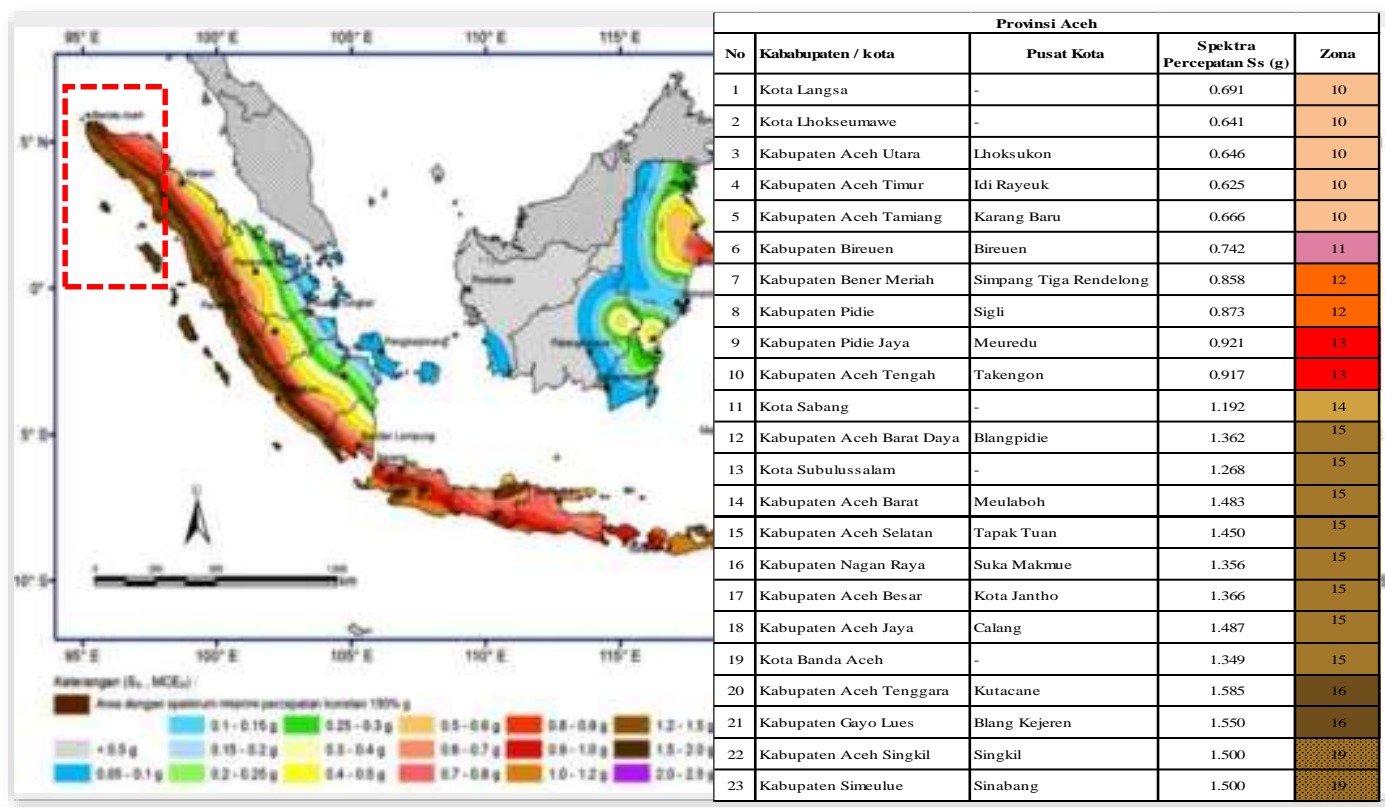

Gambar 2. Zonasi dan percepatan spektra di Provinsi Aceh [14] 
c) Perencanaan struktur kolom

Kolom termasuk dalam komponen struktur sistem rangka pemikul momen khusus. Dimensi awal penampang kolom yang digunakan pada Zona 10 adalah $25 / 25 \mathrm{~cm}^{2}$ dan tinggi kolom tiap lantai $4 \mathrm{~m}$. Rasio tulangan longitudinal $(R T)$ yang merupakan perbandingan luas total penampang tulangan dan luas penampang beton dipertahankan dalam rentang 1\% - 6\% (lebih besar dari ketentuan minimum sebesar $0,25 \%$ pada SNI 1726:2012 Pasal 7.12.2). Bila peningkatan beban akibat perubahan respon spektra menyebabkan peningkatan rasio melebihi rentang tersebut, maka akan dilakukan penyesuaian pada dimensi penampang kolom.

3) Pemodelan struktur

Pemodelan struktur dilakukan dengan alat bantu perangkat lunak SAP 2000 v.20.0.0 Ultimate International Academic, dengan memberikan pembebanan berdasarkan SNI 1727:2013. Luaran (output) yang dihasilkan berupa dimensi luas penampang beton $(A k)$, luas penampang tulangan $(A t)$, dan rasio tulangan longitudinal $(R T)$. Khusus untuk perencanaan tulangan pada tiap kolom, informasi luas penampang tulangan digunakan sebagai dasar perencanaan jumlah dan diameter tulangan. Karena dimensi penampang kolom diasumsikan bujur sangkar, maka jumlah tulangan direncanakan berjumlah sama pada keempat sisi kolom.

\subsection{Analisis Kuantitas Material}

Kebutuhan material beton bertulang dihitung pada seluruh kolom menurut lantai bangunan. Analisis kuantitas ini terbagi pada kuantitas beton dan kuantitas tulangan. Kuantitas beton $(K B)$ ditentukan berdasarkan luas penampang kolom $\left(A k_{i}\right)$, tinggi kolom $\left(T_{i}\right)$, jumlah kolom $\left(n_{i}\right)$, dan ditetapkan dalam satuan meter kubik, sesuai dengan Persamaan 1. Sedangkan kuantitas tulangan $(K T)$ ditentukan berdasarkan panjang tiap jenis tulangan $\left(L_{i}\right)$, jumlah batang $\left(n_{i}\right)$, dan kemudian dikonversi dengan faktor panjang ke berat $\left(c_{i}\right)$. Ukuran kuantitas dinyatakan dalam satuan kilogram (kg), sesuai dengan Persamaan 2. Proses analisis dilakukan dengan menggunakan formulir quantity take-off dengan bantuan aplikasi spreadsheet.

$$
\begin{aligned}
& K B=\sum_{i=1}^{n} n_{i} \cdot A k_{i} \cdot T_{i} \\
& K T=\sum_{i=1}^{n} n_{i} \cdot L_{i} \cdot c_{i}
\end{aligned}
$$

\section{HASIL DAN PEMBAHASAN}

\subsection{Dimensi struktur kolom}

Hasil yang diperoleh dari proses pemodelan struktur adalah berupa informasi dimensi dalam bentuk luas penampang kolom $\left(A_{k}\right)$ luas penampang tulangan $\left(A_{t}\right)$, sebagaimana diperlihatkan pada Tabel 1. Bila diperhatikan pada dimensi penampang kolom, luas penampang yang dibutuhkan untuk bangunan di seluruh zona tidak mengalami perubahan. Sebaliknya untuk luas tulangan, pada kolom di lantai 1 bangunan terlihat adanya perubahan berupa peningkatan yang terlihat mulai pada bangunan di Zona 13.

\begin{tabular}{|c|c|c|c|c|c|c|c|}
\hline \multirow{2}{*}{$\begin{array}{l}\text { Zona } \\
\text { Gempa }\end{array}$} & \multirow{2}{*}{$\begin{array}{l}\text { Respon } \\
\text { Spektra } \\
(g)\end{array}$} & \multicolumn{3}{|c|}{ Kolom Lantai 1} & \multicolumn{3}{|c|}{ Kolom Lantai 2} \\
\hline & & $\begin{array}{r}A k \\
\left(\mathbf{m m}^{2}\right)\end{array}$ & $\begin{array}{r}A t \\
\left(\mathbf{m m}^{2}\right)\end{array}$ & $\begin{array}{r}R T \\
(\%)\end{array}$ & $\begin{array}{r}A k \\
\left(\mathbf{m m}^{2}\right)\end{array}$ & $\begin{array}{r}A t \\
\left(\mathbf{m m}^{2}\right)\end{array}$ & $\begin{array}{c}R T \\
(\%)\end{array}$ \\
\hline 10 & 0,69 & 62.500 & 625 & 1,00 & 62.500 & 625 & 1,00 \\
\hline 11 & 0,74 & 62.500 & 625 & 1,00 & 62.500 & 625 & 1,00 \\
\hline 12 & 0,87 & 62.500 & 625 & 1,00 & 62.500 & 625 & 1,00 \\
\hline 13 & 0,92 & 62.500 & 644 & 1,03 & 62.500 & 625 & 1,00 \\
\hline 14 & 1,19 & 62.500 & 931 & 1,49 & 62.500 & 625 & 1,00 \\
\hline 15 & 1,49 & 62.500 & 1.159 & 1,85 & 62.500 & 625 & 1,00 \\
\hline 16 & 1,59 & 62.500 & 1.357 & 2,17 & 62.500 & 625 & 1,00 \\
\hline 19 & 1,50 & 62.500 & 1.161 & 1,85 & 62.500 & 625 & 1,00 \\
\hline
\end{tabular}

Tabel 1. Dimensi kolom dan tulangan 
Luas penampang kolom masih dapat dipertahankan dimensinya untuk seluruh zona mengingat rasio tulangan longitudinal $(R T)$ yang diperoleh masih dalam rentang rasio rencana antara $1 \%$ sampai dengan $6 \%$. Penyesuaian atau perubahan pada dimensi penampang kolom hanya dibutuhkan bila rasio yang muncul dari analisis luas tulangan rencana mengindikasikan nilai rasio di atas rentang acuan tersebut. Kondisi tersebut menunjukkan bahwa peningkatan beban cenderung berdampak lebih dahulu pada perubahan luas tulangan, dan baru diikuti perubahan pada luas penampang kolom bila rasio tulangan acuan terlampaui.

Bila diamati dari aspek luas tulangan, perubahan hanya terlihat pada kolom di lantai 1 bangunan, sedangkan pada kolom di lantai 2 tidak terjadi perubahan. Kondisi ini merupakan konsekuensi dari akumulasi beban yang diterima suatu komponen struktur kolom dari beban konstruksi di atasnya. Kolom pada lantai 2 hanya berperan menahan beban dari struktur atap bangunan saja. Secara grafis, perubahan dimensi luas pada tiap zona ditunjukkan dalam Gambar 3.

\subsection{Perubahan material struktur kolom beton bertulang}

Material struktur yang dianalisis disesuaikan dengan komponen beton bertulang, yaitu material beton dan material baja tulangan.

\subsubsection{Material Beton}

Kuantitas beton pada struktur kolom ditentukan oleh variabel luas penampang beton $\left(A k_{\mathrm{i}}\right)$, tinggi kolom $\left(T_{i}\right)$, dan jumlah kolom $\left(n_{i}\right)$. Hasil perhitungan kuantitas beton yang diperoleh pada struktur kolom di tiap lantai bangunan untuk seluruh zona tidak memperlihatkan adanya perubahan. Kondisi ini mengindikasikan bahwa luas penampang yang ditentukan pada proses hasil analisis dimensi $\left(25 / 25 \mathrm{~cm}^{2}\right)$ masih tetap layak dipertahankan. Model bangunan yang direncanakan merupakan bangunan yang simetris baik dari sisi datar maupun dari sisi tegak. Hasil analisis kuantitas beton ditunjukkan pada Tabel 2 .

\subsubsection{Material Tulangan}

Penentuan kuantitas tulangan diawali dengan perencanaan jumlah dan diameter tulangan, baik untuk tulangan pokok (longitudinal) maupun tulangan sengkang (transversal). Informasi luas penampang tulangan dari hasil analisis dimensi pada tiap penampang kolom menjadi acuan dalam pemilihan jumlah dan diameter tulangan. Kuantitas tulangan dianalisis berdasarkan total panjang batang tulangan untuk tiap ukuran tulangan, dan kemudian dikonversi dalam satuan berat, sebagaimana ditunjukkan dalam Tabel 3.

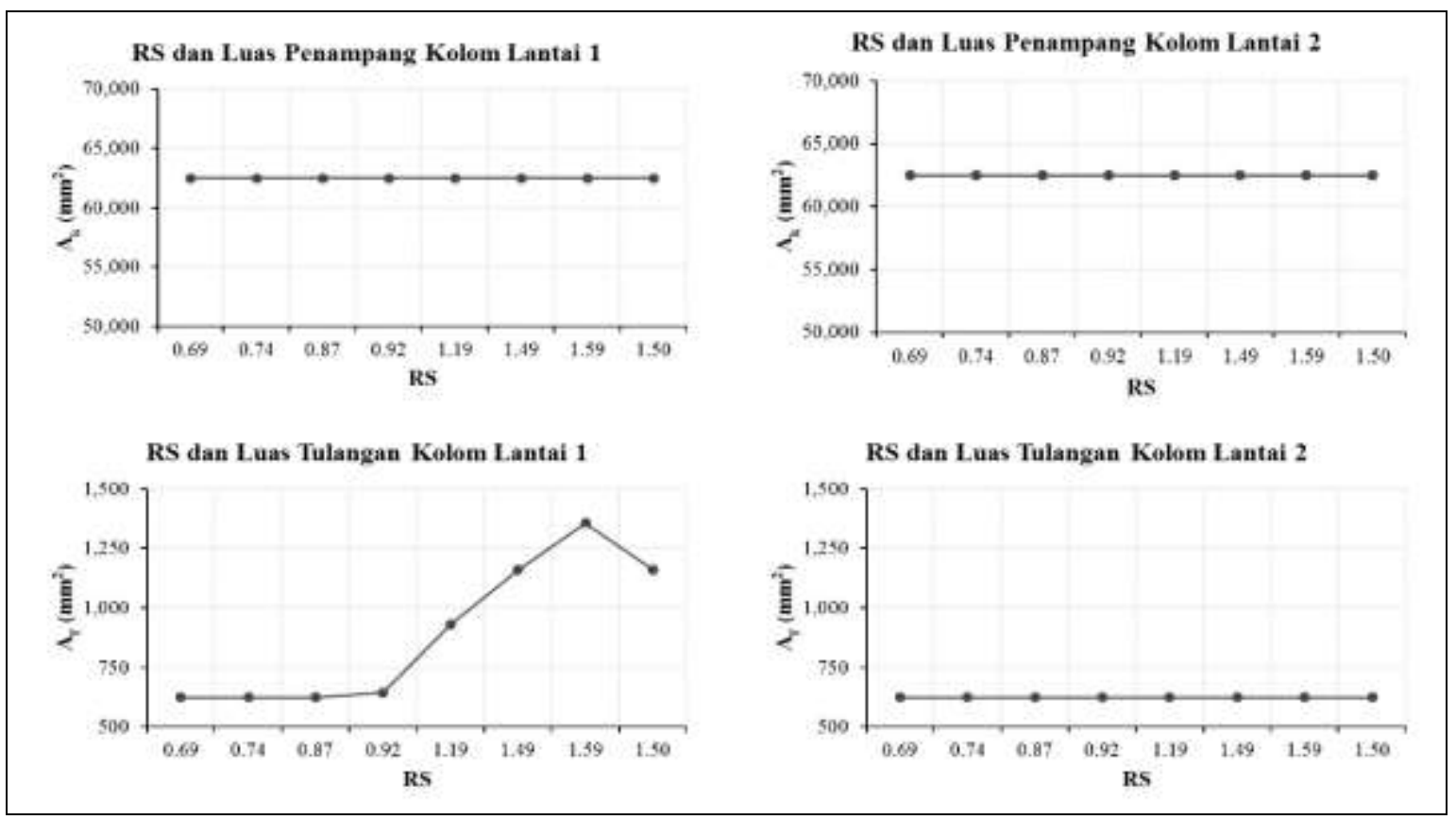

Gambar 3. Pola perubahan dimensi berdasarkan respon spektra 
Kuantitas tulangan mulai menunjukkan perubahan mulai dari Zona 14 untuk kolom pada Lantai 1, sedangkan pada kolom Lantai 2 tidak terjadi perubahan. Perubahan kuantitas pada kolom Lantai 1 menunjukkan adanya sedikit pergeseran dibandingkan dengan hasil analisis dimensi. Pergeseran tersebut terlihat dari posisi perubahan dimensi luas penampang yang terjadi mulai dari Zona 13. Hal ini dapat terjadi akibat selisih kebutuhan luas penampang yang kecil pada Zona 13 dan Zona $12\left(\Delta A t=19 \mathrm{~mm}^{2}\right)$. Ketika tulangan pada zona tersebut direncanakan menggunakan besi 8D12, luas penampang tulangan tersedia $\left(905 \mathrm{~mm}^{2}\right)$ masih memenuhi luas minimum yang dibutuhkan pada kedua zona tersebut.

\subsubsection{Rasio penggunaan tulangan per $\mathrm{m}^{3}$ beton}

Rasio ini menjelaskan jumlah penggunaan material tulangan untuk tiap $\mathrm{m}^{3}$ beton. Rasio penggunaan tulangan ini ditentukan dari perbandingan antara total kuantitas tulangan $(K T)$ dan total kuantitas beton $(K B)$. Penentuan rasio ini dilakukan berdasarkan kuantitas di tiap level lantai bangunan dan berdasarkan kuantitas secara keseluruhan. Perubahan pola rasio penggunaan tulangan di tiap zona mengikuti perubahan pada kuantitas kedua jenis material. Perubahan rasio penggunaan tulangan hanya terlihat pada kolom lantai 1 saja, sedangkan untuk kolom di lantai 2 tidak ada perubahan. Pola perubahan tersebut ditunjukkan dalam Gambar 4.

Tabel 2. Perubahan penggunaan material beton

\begin{tabular}{|c|c|c|c|c|c|c|c|c|c|c|}
\hline \multirow{2}{*}{$\begin{array}{l}\text { Zonasi } \\
\text { Gempa }\end{array}$} & \multirow{2}{*}{$\begin{array}{l}\text { Respon } \\
\text { Spektra }\end{array}$} & \multicolumn{4}{|c|}{ Kolom Lantai 1} & \multicolumn{4}{|c|}{ Kolom Lantai 2} & \multirow{2}{*}{$\begin{array}{c}\text { Total } \\
\boldsymbol{K B} \\
\left(\mathbf{m}^{3}\right)\end{array}$} \\
\hline & & $\begin{array}{c}A k_{i} \\
\left(\mathbf{m}^{2}\right)\end{array}$ & $\begin{array}{c}T_{i} \\
(\mathbf{m})\end{array}$ & $N_{i}$ & $\begin{array}{l}\boldsymbol{K} \boldsymbol{B}_{\boldsymbol{I}} \\
\left(\mathbf{m}^{\mathbf{3}}\right)\end{array}$ & $\begin{array}{c}A k_{i} \\
\left(\mathbf{m}^{2}\right)\end{array}$ & $\begin{array}{c}T_{i} \\
(\mathbf{m})\end{array}$ & $N_{i}$ & $\begin{array}{l}K B_{2} \\
\left(\mathbf{m}^{3}\right) \\
\end{array}$ & \\
\hline 10 & 0,69 & 0,625 & 4 & 24 & 6,0 & 0,625 & 4 & 24 & 6,0 & 12,0 \\
\hline 11 & 0,74 & 0,625 & 4 & 24 & 6,0 & 0,625 & 4 & 24 & 6,0 & 12,0 \\
\hline 12 & 0,87 & 0,625 & 4 & 24 & 6,0 & 0,625 & 4 & 24 & 6,0 & 12,0 \\
\hline 13 & 0,92 & 0,625 & 4 & 24 & 6,0 & 0,625 & 4 & 24 & 6,0 & 12,0 \\
\hline 14 & 1,19 & 0,625 & 4 & 24 & 6,0 & 0,625 & 4 & 24 & 6,0 & 12,0 \\
\hline 15 & 1,49 & 0,625 & 4 & 24 & 6,0 & 0,625 & 4 & 24 & 6,0 & 12,0 \\
\hline 16 & 1,59 & 0,625 & 4 & 24 & 6,0 & 0,625 & 4 & 24 & 6,0 & 12,0 \\
\hline 19 & 1,50 & 0,625 & 4 & 24 & 6,0 & 0,625 & 4 & 24 & 6,0 & 12,0 \\
\hline
\end{tabular}

Tabel 3. Perubahan penggunaan material baja tulangan

\begin{tabular}{|c|c|c|c|c|c|c|c|c|}
\hline \multirow{2}{*}{$\begin{array}{l}\text { Zonasi } \\
\text { Gempa }\end{array}$} & \multirow{2}{*}{$\begin{array}{l}\text { Respon } \\
\text { Spektra }\end{array}$} & \multicolumn{3}{|c|}{ Kolom Lantai 1} & \multicolumn{3}{|c|}{ Kolom Lantai 2} & \multirow{2}{*}{$\begin{array}{c}\text { Total } \\
K T \\
(\mathbf{k g})\end{array}$} \\
\hline & & $\begin{array}{c}\text { Tulangan } \\
\text { Pokok }\end{array}$ & $\begin{array}{c}\text { Sengkang } \\
\text { (Tmp-Lpg) }\end{array}$ & $\begin{array}{l}K T_{1} \\
(\mathbf{k g})\end{array}$ & $\begin{array}{c}\text { Tulangan } \\
\text { Pokok }\end{array}$ & $\begin{array}{c}\text { Sengkang } \\
\text { (Tmp-Lpg) }\end{array}$ & $\begin{array}{l}K T_{2} \\
(\mathbf{k g})\end{array}$ & \\
\hline 10 & 0,69 & 8D12 & $\begin{array}{l}\text { D10-100 } \\
\text { D10-150 }\end{array}$ & $1.113,59$ & 8D12 & $\begin{array}{l}\text { D10-100 } \\
\text { D10-150 }\end{array}$ & $1.023,26$ & $2.136,85$ \\
\hline 11 & 0,74 & 8D12 & $\begin{array}{l}\text { D10-100 } \\
\text { D10-150 }\end{array}$ & $1.113,59$ & 8D12 & $\begin{array}{l}\text { D10-100 } \\
\text { D10-150 }\end{array}$ & $1.023,26$ & $2.136,85$ \\
\hline 12 & 0,87 & 8D12 & $\begin{array}{l}\text { D10-100 } \\
\text { D10-150 }\end{array}$ & $1.113,59$ & $8 \mathrm{D} 12$ & $\begin{array}{l}\text { D10-100 } \\
\text { D10-150 }\end{array}$ & $1.023,26$ & $2.136,85$ \\
\hline 13 & 0,92 & $8 \mathrm{D} 12$ & $\begin{array}{l}\text { D10-100 } \\
\text { D10-150 }\end{array}$ & $1.113,59$ & 8D12 & $\begin{array}{l}\text { D10-100 } \\
\text { D10-150 }\end{array}$ & $1.023,26$ & $2.136,85$ \\
\hline 14 & 1,19 & $8 \mathrm{D} 13$ & $\begin{array}{l}\text { D10-100 } \\
\text { D10-150 }\end{array}$ & $1.265,27$ & 8D12 & $\begin{array}{l}\text { D10-100 } \\
\text { D10-150 }\end{array}$ & $1.023,26$ & $2.288,52$ \\
\hline 15 & 1,49 & 8D14 & $\begin{array}{l}\text { D10-100 } \\
\text { D10-150 }\end{array}$ & $2.280,34$ & $8 \mathrm{D} 12$ & $\begin{array}{l}\text { D10-100 } \\
\text { D10-150 }\end{array}$ & $1.023,26$ & $3.303,60$ \\
\hline 16 & 1,59 & $8 \mathrm{D} 16$ & $\begin{array}{l}\text { D10-100 } \\
\text { D10-150 } \\
\end{array}$ & $2.564,35$ & $8 \mathrm{D} 12$ & $\begin{array}{l}\text { D10-100 } \\
\text { D10-150 }\end{array}$ & $1.023,26$ & $3.587,60$ \\
\hline 19 & 1,50 & 8D14 & $\begin{array}{l}\text { D10-100 } \\
\text { D10-150 }\end{array}$ & $2.280,34$ & 8D12 & $\begin{array}{l}\text { D10-100 } \\
\text { D10-150 }\end{array}$ & $1.023,26$ & $3.303,60$ \\
\hline
\end{tabular}




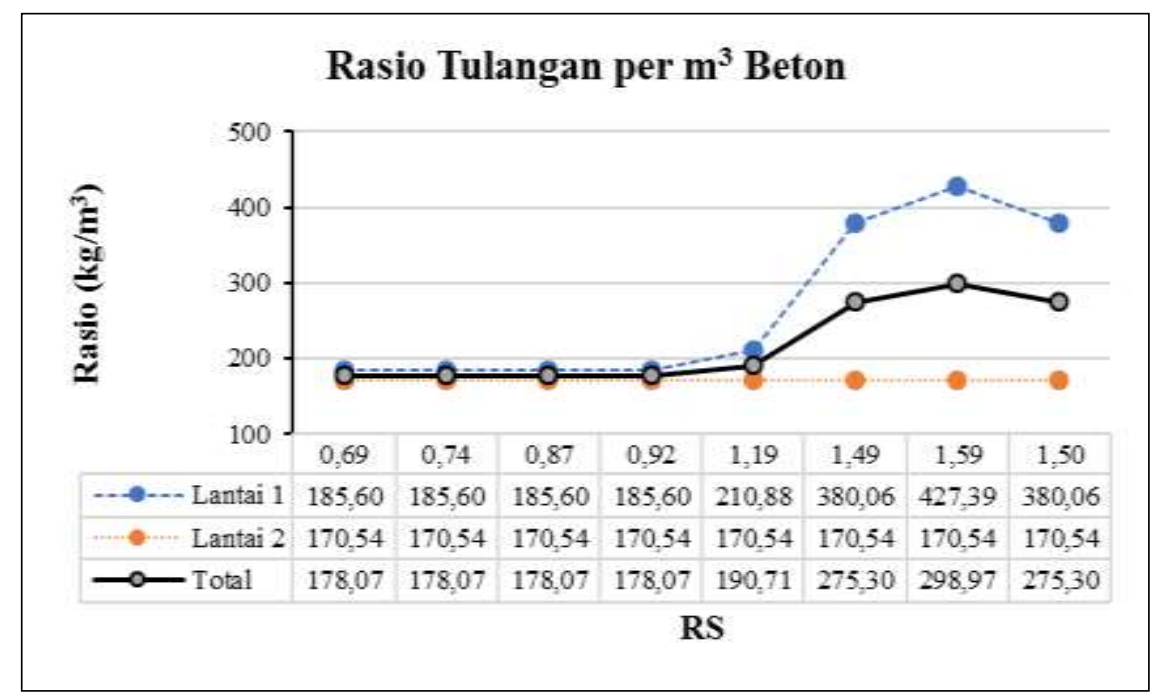

Gambar 4. Pola perubahan rasio kuantitas tulangan dan beton

\section{KESIMPULAN DAN SARAN \\ 4.1. Kesimpulan}

Penelitian ini telah mengidentifikasi sejumlah informasi terkait dengan perubahan penggunaan material beton bertulang pada seluruh zona gempa di Provinsi Aceh. Hasil analisis struktur pada desain model struktur bangunan sederhana, perubahan dimensi struktur terlihat pada aspek luas tulangan kolom di lantai 1 bangunan. Perubahan ini mengindikasikan adanya pengaruh perubahan beban akibat gempa terhadap perubahan dimensi struktur, walaupun tidak seluruh dimensi ikut terpengaruh. Pola perubahan pada dimensi baik untuk komponen beton dan tulangan secara langsung akan memberikan pola perubahan yang sama dari aspek penggunaan material. Dari sisi rasio penggunaan tulangan, pola perubahan rasio yang terjadi juga identik mengikuti pola penggunaan material.

\subsection{Saran}

Hasil yang diperoleh pada penelitian ini masih memberikan informasi yang terbatas pada lingkup kajian ini saja. Untuk memahami secara lebih menyeluruh terkait aspek perubahan penggunaan material, diperlukan sejumlah langkah kajian lanjutan dengan perluasan lingkup kajian.

\section{UCAPAN TERIMA KASIH}

Penelitian ini terlaksana atas dukungan pendanaan dari Hibah PLK Tahun Anggaran 2018, sesuai dengan Surat Perjanjian Penugasan
Pelaksanaan Penelitian Nomor 288/UN11/SP/PNBP/2018 pada Lembaga Penelitian dan Pengabdian Kepada Masyarakat Universitas Syiah Kuala. Penulis menyampaikan apresiasi dan ucapan terima kasih kepada seluruh tim peneliti serta pihak lainnya yang telah berkontribusi hingga selesainya penelitian ini.

\section{DAFTAR PUSTAKA}

[1] Asrurifak, 2017, Peta Gempa Indonesia 2017 dan Aplikasinya untuk Perencanaan Gedung dan Infrastruktur Tahan Gempa, Slide presentasi Workshop Pengurangan Risiko Bencana Gempa Kota Surabaya \& Jawa Timur.

[2] SNI 1726:2012 tentang Tata Cara Perencanaan Ketahanan Gempa untuk Bangunan Gedung dan Non Gedung, Badan Standardisasi Nasional, Jakarta.

[3] Yépez, F., and Yépez, O., 2017, 'Role of construction materials in the collapse of $\mathrm{R} / \mathrm{C}$ buildingsafter Mw 7.8 Pedernales - Ecuador earthquake, April 2016', Case Studies in Structural Engineering, 7, 24-31.

[4] Yoshikawa, H., and Goda, K., 2014, 'Financial Seismic Risk Analysis of Building Portfolios', Nat. Hazards Rev., 15(2), 112-120.

[5] Tas, E., and Yaman, H., 2005, 'A building cost estimation model based on cost significant work packages', Engineering, Construction and Architectural Management, 12(3), 251-263.

[6] Mubarak, 2010, 'Studi Harga Satuan Bangunan Gedung di Provinsi Nanggroe Aceh Darussalam', Jurnal Teknik Sipil, 1(1), 43-52.

[7] Mubarak, Tripoli, and Nurisra, 2018, 'The Unit 
Price Implication of Reinforcement Usage in Tie Beam Reinforced Concrete Construction', Aceh Int. J. Sci. Technol., 5(1), 24-31.

[8] Tripoli, Mubarak, Nurisra, dan Mahmuddin, 2018, 'The implementation of unit price of work standard SNI 7394: 2008 for the construction of reinforced concrete beam', IOP Conf. Series: Materials Science and Engineering, 352, 012027.

[9] Tripoli, Nurisra, dan Mubarak, 2017, 'Analisis kebutuhan tulangan pelat lantai beton bertulang pada konstruksi bangunan gedung', Konferensi Nasional Teknik Sipil 11, 1-9.

[10] Mubarak, Abdullah, Riza, M., dan Hayati, Y., 2018, 'Perubahan penggunaan material plat lantai beton bertulang disebabkan perbedaan zonasi gempa', Konferensi Nasional Teknik Sipil 12, 327-334.

[11] Peraturan Menteri Pekerjaan Umum Nomor 45/PRT/M/2007 Tentang Pedoman Teknis Pembangunan Bangunan Gedung Negara.

[12] SNI 1727:2013 tentang Beban Minimum untuk Perancangan Bangunan Gedung dan Struktur Lain, Badan Standardisasi Nasional, Jakarta.

[14] Pusat Penelitian dan Pengembangan Permukiman PU, 2010, Peta Zonasi Gempa Indonesia, tersedia pada http://puskim.pu.go.id/Aplikasi/desain_spektra _indonesia_2011/, diakses 10 Februari 2018. 